\title{
Determination of LDL Cholesterol and LDL Apolipoprotein B Following Precipitation of VLDL in Blood Serum with Phosphotungstic Acid/ $\mathrm{MgCl}_{2}$
}

By $H$. Schriewer,

Zentrallaboratorium der Medizinischen Einrichtungen der Westfälischen Wilhelms-Universität, Münster

\author{
U. Kohnert
}

Institut für Biochemie der Westfälischen Wilhelms-Universität, Münster and

\section{G. Assmann}

Zentrallaboratorium der Medizinischen Einrichtungen der Westfälischen Wilhelms-Universität, Münster

(Received June 9/October 31, 1983)

Summary: A method is described for the selective precipitation of VLDL in blood serum using phosphotungstic acid/ $\mathrm{MgCl}_{2}$. The method allows for the calculation of $\mathrm{LDL}$ apolipoprotein $\mathrm{B}$ as well as for the calculation of LDL cholesterol (following the additional determination of HDL cholesterol). Dependent on the triglyceride and the cholesterol content of the serum, three different procedures were developed using phosphotungstic acid and $\mathrm{MgCl}_{2}$ in different concentrations in the precipitation assay. Within the tested range of 3-10 $\mathrm{mmol} / 1$ total cholesterol and 1-4 mmol/1 triglyceride in blood serum the VLDL were nearly completely precipitated with negligible coprecipitation of LDL and HDL, but $40-50 \%$ coprecipitation of $\mathrm{Lp}(\mathrm{a})$.

Regression analysis of the cholesterol values obtained by precipitation with phosphotungstic acid/ $\mathrm{MgCl}_{2}(=$ serum cholesterol - LDL cholesterol), and the cholesterol values obtained by ultracentrifugation $(\mathrm{d}>1.006$ $\mathrm{kg} / \mathrm{l})$ revealed a good measure of agreement $(\mathrm{r}=0.97, \mathrm{y}=0.93 \mathrm{x}+0.35, \mathrm{n}=76)$. An equally good measure of agreement was found for the corresponding apolipoprotein $B$ values $(r=0.96, y=1.03 x-0.2, n=61)$. In the determination of LDL cholesterol a variation coefficient of $4.3 \%(n=20)$ was found in relation to the precision in the series, and a variation coefficient of $4.8 \%(n=25)$ in relation to day to day precision.

Bestimmung von $L D L=$ Cholesterin und $L D L$-Apolipoprotein $B$ nach Fällung von VLDL im Blutserum mittels Phosphorwolframsäure/ $\mathrm{MgCl}_{2}$

Zusammenfassung: Es wird eine Methode zur selektiven Fällung von VLDL im Blutserum mittels Phosphorwolframsäure $/ \mathrm{MgCl}_{2}$ beschrieben. Die Methode erlaubt die Ermittlung von LDL-Apolipoprotein B sowie die Ermittlung von LDL-Cholesterin (nach zusätzlicher Bestimmung von HDL-Cholesterin). Abhängig vom Triglycerid- und Cholesteringehalt des Serums wurden drei verschiedene Fällungsverfahren mit unterschiedlichen Phosphorwolframsäure- und $\mathrm{MgCl}_{2}$-Konzentrationen im Fällungsansatz entwickelt. Innerhalb des untersuchten Bereichs von 3-10 mmol/1 Gesamtcholesterin und 1-4 mmol/1 Triglyceriden im Blutserum wurden die VLDL nahezu komplett präzipitiert bei zu vernachlässigender Mitpräzipitation von LDL und HDL aber 40-50\%iger Mitpräzipitation von $L p(a)$.

Die Regressionsanalyse der nach der Fällung mit Phosphorwolframsäure/ $\mathrm{MgCl}_{2}$ ermittelten Cholesterinwerte (= Serum Cholesterin - VLDL-Cholesterin) und der durch Ultrazentrifugation $(\mathrm{d}>1,006 \mathrm{~kg} / \mathrm{l})$ ermittelten Cholesterinwerte ergab eine gute Ubereinstimmung der Wertepaare $(r=0,97, y=0,93 x+0,35, n=76)$. 
Eine ähnlich gute Ưbereinstimmung wurde auch für die korrespondierenden Apolipoprotein B-Werte gefunden $(r=0,96, y=1,03 x-0,2, n=61)$. Der Variationskoeffizient der LDL-Cholesterinbestimmung hinsichtlich der Präzision in der Serie betrug 4,3\% $(n=20)$ und hinsichtlich der Präzision von Tag zu Tag $4,8 \%(n=25)$.

\section{Introduction}

About $70 \%$ of the total serum cholesterol found in blood serum is a component of the low density lipoproteins (LDL) which are considered to be atherogenic lipoproteins (1). About $25 \%$ of the total serum cholesterol is a component of the high density lipoproteins (HDL) which are thought to be anti-atherogenic lipoproteins $(2,3,4)$. Whereas HDL cholesterol can be analysed relatively easily in the supernatant after precipitation of apolipoprotein B-containing lipoproteins in serum, the direct determination of LDL cholesterol is, at the moment, only possible through isolation of LDL cholesterol using ultracentrifugation, which is technically elaborate, time consuming and limited in capacity. Calculation of LDL cholesterol using the Friedewald formula (5) results in only approximate values and cannot be used for strong hypertriglyceridaemic sera, or for sera of patients affected by type III hyperlipoproteinaemia (6).

Recently Sirowej et al. (7) described a method for the analysis of lipoproteins which is based on the sequential precipitation of lipoproteins using phosphotungstic acid/ $\mathrm{MgCl}_{2}$ as developed by Burstein et al. (8). Using this procedure as a base we developed a method for the determination of LDL cholesterol and LDL apolipoprotein $B$ which involves the precipitation of VLDL from serum using phosphotungstic acid/ $\mathrm{MgCl}_{2}$. The following is a report on the accuracy, linearity and precision of this method, and interference by other factors.

\section{Materials and Methods}

Sample material

As test material we used fresh serum from the study programme: "Prospective epidemiological study in company employees in Westfalia" (9).

Methods

\section{Preparative isolation of lipoproteins by ultracentrifugation}

Ultracentrifugation was carried out in a 40.3 rotor (Beckman Instruments) at $+4^{\circ} \mathrm{C}$. For the isolation of the $\mathrm{d}<1.006 \mathrm{~kg} / \mathrm{l}$ and the $\mathrm{d}>1.006 \mathrm{~kg} / \mathrm{l}$ fractions, $5 \mathrm{ml}$ serum were overlayered with a $0.15 \mathrm{~mol} / 1 \mathrm{NaCl}$ solution and centrifuged for 24 hours at $120000 \mathrm{~g}$. The infranatant obtained by "tube slicing" $(2.0 \mathrm{~cm}$ from the top) ( $\mathrm{d}>1.006 \mathrm{~kg} / \mathrm{l}$ fraction) was diluted to the original volume. The $\mathrm{d}<1.006 \mathrm{~kg} / \mathrm{l}$ supernatant was overlayered with an $0.15 \mathrm{~mol} / \mathrm{NaCl}$ solution and again centrifuged for $24 \mathrm{~h}$ at $120000 \mathrm{~g}$. The resultant supernatant fraction $(\mathrm{d}<1.006 \mathrm{~kg} / \mathrm{l})$ was used immediately for labeling with radioactivity.
For the isolation of $\mathrm{HDL}(\mathrm{d} 1.063-1.21 \mathrm{~kg} / \mathrm{l}), 5 \mathrm{ml}$ serum were adjusted with solid $\mathrm{KBr}$ to a density of $1.063 \mathrm{~kg} /$, overlayered with a $1.063 \mathrm{~kg} / \mathrm{A} \mathrm{KBr}$ solution and centrifuged for 24 hours at $120000 \mathrm{~g}$. The bottom fraction (d $1.063 \mathrm{~kg} / \mathrm{l})$ was adjusted with solid $\mathrm{KBr}$ to a density of $1.21 \mathrm{~kg} /$, overlayered with a $1.21 \mathrm{~kg} / \mathrm{l}$ $\mathrm{KBr}$ solution and centrifuged for 48 hours at $120000 \mathrm{~g}$. The top fraction (d $1.063-1.21 \mathrm{~kg} / \mathrm{l})$ obtained by tube slicing was dialysed exhaustively against $0.15 \mathrm{~mol} / \mathrm{NaCl}$.

\section{Preparation of radioactively labeled $V L D L$}

We labeled VLDL with tri- $\left[9,10-{ }^{3} \mathrm{H}\right]$ oleoyl glycerol using Fieldings method (10). A solution $(100 \mu \mathrm{l})$ of tri- $-\left[9,10{ }^{3} \mathrm{H}\right]$ oleoyl glycerol in dimethylsulphoxide (2.3 MBq/ml dimethylsulphoxide) was mixed with $400 \mu \mathrm{l} 0.15 \mathrm{~mol} / \mathrm{NaCl}$ and $300 \mu \mathrm{l}$ of the $\mathrm{d}<1.006 \mathrm{~kg} / 1$ ultracentrifugation fraction (protein $1.2 \mathrm{~g} / \mathrm{l}$ ) and incubated for $3 \mathrm{~h}$ at $37^{\circ} \mathrm{C}$. Following exhaustive dialysis against $0.15 \mathrm{~mol} / 1 \mathrm{NaCl}$, the VLDL radioactively labeled in the triglyceride moiety were re-isolated by ultracentrifugation - see above.

\section{Preparation of radioactively labeled $H D L$}

The preparation of $\left[{ }^{3} \mathrm{H}\right]$ cholesteryl linoleate $\mathrm{HDL}$ was carried out as described in detail elsewhere (11). The preparation of $\mathrm{HDL}$ selectively labeled in the apoprotein moiety was carried out by reductive methylation with $\left[{ }^{14} \mathrm{C}\right]$ formaldehyde, as described in detail elsewhere (12).

\section{Precipitation of $V L D L$ with phosphotungstic acid/MgCl}

Serum $(250 \mu \mathrm{l})$ was mixed with $14.4 \mathrm{~g} / \mathrm{l}$ phosphotungstic acid solution and $2 \mathrm{~mol} / 1 \mathrm{MgCl}_{2}$ solution in an incubation tube (Sarstedt No. 52690). The reagent volumes were varied, depending on the triglyceride and cholesterol content of the samples (tab. 1). Both reagents can be stored for at least four months at a temperature of $+4{ }^{\circ} \mathrm{C}$. The mixture was incubated for 25 minutes in an ice bath at $0^{\circ} \mathrm{C}$, then centrifuged for 5 minutes in an Eppendorf centrifuge 3200. The VLDL free serum was separated from the floated supernatant with the aid of an injection needle.

\section{Apolipoprotein $B$ assay}

Apolipoprotein B was determined by means of kinetic nephelometry using the Beckman Immuno-Chemical-System according to the following method (manual mode card M 33).

The following were pipetted into special cuvettes with stirrers: $600 \mu \mathrm{l}$ of a polyethylene-glycol solution (Beckman ICS-System)

$42 \mu \mathrm{l}$ of diluted sample (100 $\mu \mathrm{l}$ sample and $6900 \mu \mathrm{l} 0.15 \mathrm{~mol} / \mathrm{l}$ $\mathrm{NaCl})$ and

$42 \mu \mathrm{l}$ of antibody solution (Behring Werke, D-3550 Marburg, order no. SAN 04) (diluted 1:4 with phosphate buffered polyethylenglycol solution).

Recording of the reaction was started immediately after addition of the antibody solution. Standard solutions diluted with $0.15 \mathrm{~mol} / \mathrm{N} \mathrm{NaCl}$ solution $(1: 20,1: 30,1: 40,1: 80,1: 160)$ were used for cạlibration (Immunoneph, Reference Standard Apopro: teins Human, Immuno Comp.p., D-6900 Heidelberg, order No. 4380105). 


\section{Lipoprotein (a) assay}

For the determination of lipoprotein (a) $(L p(a))$ in blood serum, one dimensional Laurell immunoelectrophoresis (13) was used. As antibody we used antihuman-Lp(a) from sheep (Immuno Comp., D-6900 Heidelberg, order No. 4845005); standard Lp(a) human (Immuno Comp., D-6900 Heidelberg, order No. 4395005) was used as standard reference material.

\section{Lipid assays}

Cholesterol was determined enzymatically using the cholesterol oxidase/4-aminophenazone-phenol method (Boehringer Mannheim, Monotest Cholesterol High Performance, order No. 237574). Triglycerides were determined fully enzymatically using the enzymatic triglyceride assay after enzymatic hydrolysis (Boehringer Mannheim "Test-Combination Triglyceride vollenzymatisch UV-Test", order No. 240052).

\section{Results}

Influence of triglycerides and cholesterol on the completeness and selectivity of VLDL precipitation

The completeness of VLDL precipitation was tested by adding tri- $\left[9,10-{ }^{3} \mathrm{H}\right]$ oleoyl glycerol VLDL to fresh sera in tracer amounts and by subsequent determination of the recovery of the radioactivity in the fraction obtained by separating the precipitate. Furthermore, lipid electrophoresis of the precipitate free fraction was performed. Coprecipitation of LDL was tested by comparing the cholesterol and the apolipoprotein $B$ values found in the precipitate free fraction with the values obtained by ultracentrifugation $(\mathrm{d}>1.006 \mathrm{~kg} / \mathrm{l})$.

With a constant concentration of phosphotungstic acid and magnesium chloride, a selective precipitation of VLDL was only possible within a limited range of cholesterol and triglyceride levels in blood serum. With increasing cholesterol and triglyceride levels in serum larger amounts of phosphotungstic acid and magnesium chloride were required for a complete and selective VLDL precipitation. Therefore, depending on the triglyceride and cholesterol content of the serum, three different procedures were developed using phosphotungstic acid and $\mathrm{MgCl}_{2}$ in three different concentrations in the precipitation assay (I, II, III). Under the conditions stated in table 1 , VLDL were almost completely precipitated irrespective of the cholesterol and triglyceride content of the serum. Following addition of radioactively labeled VLDL to sera the medium recovery of the radioactivity in the precipitate free fraction was $14 \pm 4 \%$ ( $\bar{x} \pm$ S.D.) (6 different experiments). Pre- $\beta$ lipoproteins could not be demonstrated in the lipid electrophoresis of the precipitate free fraction (results not shown).
Tab. 1. Volumes of phosphotungstic acid and $\mathrm{MgCl}_{2}$ solutions in precipitation analysis related to the triglyceride and cholesterol contents of the samples.

Final concentrations of phosphotungstic acid $(\mathrm{mg} / \mathrm{l})$ and $\mathrm{MgCl}_{2}(\mathrm{mmol} / \mathrm{l})$ are shown in brackets.

\begin{tabular}{|c|c|c|c|c|}
\hline $\begin{array}{l}\text { Tri- } \\
\text { glycerides } \\
\text { in serum } \\
\text { (mmol/l) }\end{array}$ & $\begin{array}{l}\text { Cholesterol } \\
\text { in serum } \\
(\mathrm{mmol} / \mathrm{l})\end{array}$ & $\begin{array}{l}\mathrm{MgCl}_{2} \\
\text { solution } \\
(2 \mathrm{~mol} / \mathrm{l}) \\
(\mu \mathrm{l})\end{array}$ & $\begin{array}{l}\text { Phospho- } \\
\text { tungstic } \\
\text { acid solution } \\
(14.4 \mathrm{~g} / \mathrm{l}) \\
(\mu \mathrm{l})\end{array}$ & $\begin{array}{l}\text { Pro- } \\
\text { ce- } \\
\text { dure }\end{array}$ \\
\hline $\begin{array}{l}1.0-2.85 \\
1.0-2.85 \\
1.0-2.85 \\
2.85-4.0 \\
2.85-4.0\end{array}$ & $\begin{array}{l}3.0-4.4 \\
4.4-5.95 \\
5.95-10.3 \\
4.4-5.2 \\
5.2-10.3\end{array}$ & $\begin{array}{l}7.6(57.4) \\
8.2(61.7) \\
9.0(67.3) \\
8.2(61.7) \\
9.0(67.3)\end{array}$ & $\begin{array}{l}7.3(397) \\
7.8(422) \\
8.6(463) \\
7.8(422) \\
8.6(463)\end{array}$ & $\begin{array}{l}\text { I } \\
\text { II } \\
\text { III } \\
\text { II } \\
\text { III }\end{array}$ \\
\hline
\end{tabular}

Regression analysis of the cholesterol values, determined after precipitation with phosphotungstic acid (y) and ultracentrifugation $(\mathrm{d}>1,006 \mathrm{~kg} / \mathrm{l})(\mathrm{x})$, resulted in a good measure of agreement between the obtained data: $r=0.97, y=0.93 x+0.35, n=76$ (fig. 1). Also, regression analysis of apolipoprotein $B$ values, determined by precipitation with phosphotungstic acid $(y)$ and ultracentrifugation $(\mathrm{d}>1.006$ $\mathrm{kg} / \mathrm{l})(\mathrm{x})$, showed a good match of the respective paired values: $\mathrm{r}=0.96, \mathrm{y}=1.03 \mathrm{x}-0.2, \mathrm{n}=61$ (fig. 2).

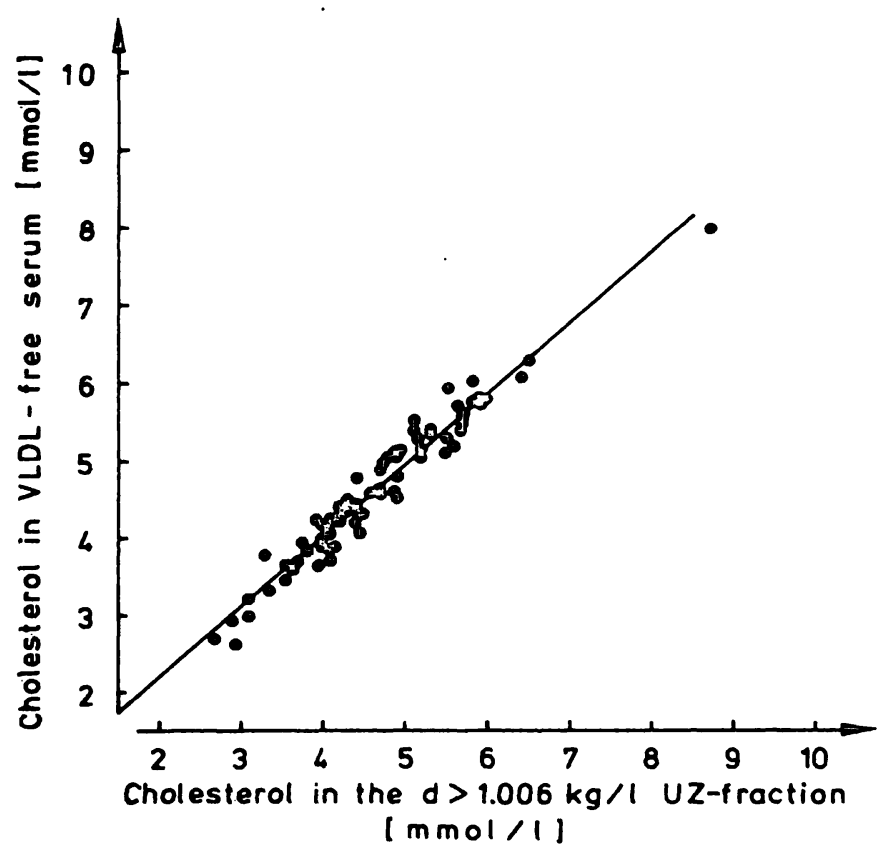

Fig. 1. Regression analysis of cholesterol values obtained from ultracentrifugation $(d>1.006 \mathrm{~kg} / \mathrm{l})(\mathrm{x})$ and from the fraction following precipitation of VLDL with phosphotungstic acid/ $\mathrm{MgCl}_{2}(y) \mathrm{r}=0.97, \mathrm{y}=0.93 \mathrm{x}+0.35, \mathrm{n}=76$. 


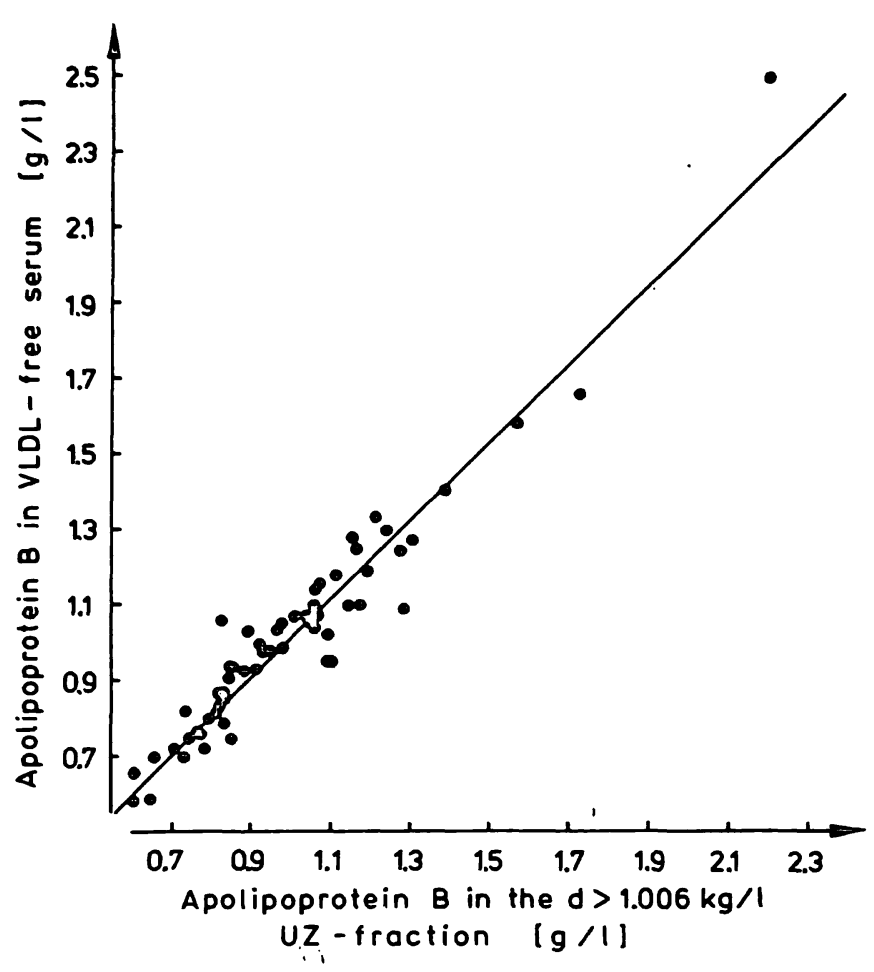

Fig. 2. Regression analysis of apolipoprotein $B$ values obtained from ultracentrifugation $(\mathrm{d}>1.006 \mathrm{~kg} / \mathrm{l})(\mathrm{x})$ and from the fraction following precipitation of VLDL with phosphotungstic acid $/ \mathrm{MgCl}_{2}(\mathrm{y}), \mathrm{r}=0.96, \mathrm{y}=1.03 \mathrm{x}-0.2, \mathrm{n}=$ 61.

\section{Coprecipitation of other lipoproteins}

The extent of coprecipitation of HDL was tested by adding tracer amounts of HDL radioactively labeled in the cholesteryl ester moiety, or in the apoprotein moiety. After separating the floating VLDL precipitate, $93 \pm 5 \%(\bar{x} \pm$ S.D.) of the added radioactive material was recovered when $\left[{ }^{3} \mathrm{H}\right]$ cholesteryl linoleate HDL had been added (five different experiments) and $94 \pm 5 \%(\bar{x} \pm$ S.D. $)$ of the added radioactive material was recovered when ${ }^{14} \mathrm{C}$ labeled HDL had been added (four different experiments).

Coprecipitation of $\mathrm{Lp}(\mathrm{a})$ was determined in a similar fashion. The results presented in table 2 show that $\mathrm{Lp}(\mathrm{a})$ was on average coprecipitated up to $40-50 \%$.

Tab. 2. Percentage of coprecipitation of $L p(a)$ in the precipitation of VLDL in fresh sera using phosphotungstic acid/ $\mathrm{MgCl}_{2}$.

\begin{tabular}{lll}
\hline$L P(a)$ in serum & $\begin{array}{l}\text { Lp (a) in VLDL } \\
\text { free fraction } \\
(\mathrm{g} / \mathrm{l})\end{array}$ & $\begin{array}{l}\text { Percentage of } \\
\text { coprecipitation }\end{array}$ \\
$(\mathrm{g} / \mathrm{l})$ & & \\
\hline 0.04 & 0.03 & 25 \\
0.06 & 0.03 & 50 \\
0.04 & 0.03 & 25 \\
0.05 & 0.03 & 40 \\
0.25 & 0.10 & 60 \\
0.37 & 0.20 & 44 \\
\hline
\end{tabular}

\section{Linearity of the precipitation method}

The linearity of this method was tested using different mixtures of two sera with high $(9.3 \mathrm{mmol} / \mathrm{l})$ and low $(4.13 \mathrm{mmol} / \mathrm{l})$ cholesterol contents. It was found that the cholesterol value measured in the fractions obtained by separating the precipitate was proportional to the ratio of components (fig. 3). When mixing two sera with cholesterol contents of $4.68 \mathrm{~mol} / \mathrm{l}$ and $2.34 \mathrm{mmol} / \mathrm{l}$, the cholesterol value determined in the fraction obtained by separating the precipitate deviated by several degrees downwards when the cholesterol concentration in the sample was less than $3.4 \mathrm{mmol} / 1$ (fig. 3).

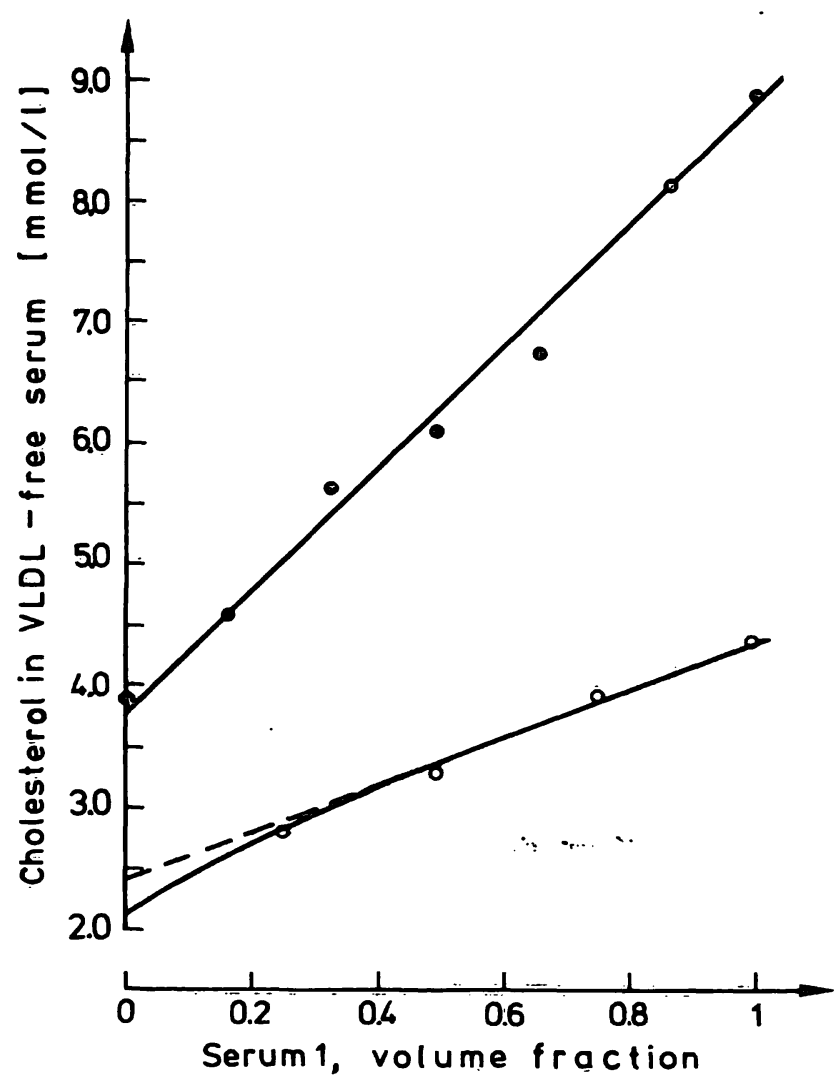

Fig. 3. Cholesterol in the fraction obtained by precipitation of VLDL with phosphotungstic acid/ $\mathrm{MgCl}_{2}$ as a function of the volume ratio when two sera with high and low cholesterol concentration were mixed.

๑-C Cholesterol serum 1: $9.30 \mathrm{mmol} / \mathrm{l}$; serum 2: 4.13 . $\mathrm{mmol} / \mathrm{l}$.

$O=O$ Cholesterol serum $1: 4.68 \mathrm{mmol} / \mathrm{l}$; serum 2: 2.34 mmol/h.

\section{Precision of the $L D L$ cholesterol determination}

With regard to the precision in the series, a variation coefficient of $4.3 \%$ was found $(\hat{n}=20)$ for $L D L$ cholesterol using a fresh serum pool. Day to day precision was tested with aliquots of fresh pool serum which, was stored in a refrigerator at $+4^{\circ} \mathrm{C}$. A variation coefficient of $4.8 \%$ was found for LDL cholesterol $(\mathrm{n}=25)$. 


\section{Other influences}

The influence of the reagent concentration on the accuracy of VLDL precipitation was very considerable. Even small changes in concentration of both precipitation reagents caused a clear change in cholesterol concentration measured in the fraction obtained by separating the precipitate (not shown).

A complete precipitation of VLDL was only possible at an incubation temperature of $0{ }^{\circ} \mathrm{C}$, but not at an incubation temperature of $25^{\circ} \mathrm{C}$ (both for $25 \mathrm{~min}$ utes). In samples which were first incubated at $25^{\circ} \mathrm{C}$ and then at $0^{\circ} \mathrm{C}$ there was no, or only incomplete precipitation. On the other hand, when the samples were first incubated at $0{ }^{\circ} \mathrm{C}$ and then at $25^{\circ} \mathrm{C}$ the precipitate dissolved. At an incubation temperature of $0^{\circ} \mathrm{C}$ the cholesterol value determined by difference (total serum cholesterol minus cholesterol in the fraction obtained by separating the precipitate) reached its maximum level after an incubation time of 20 minutes (fig. 4 ).

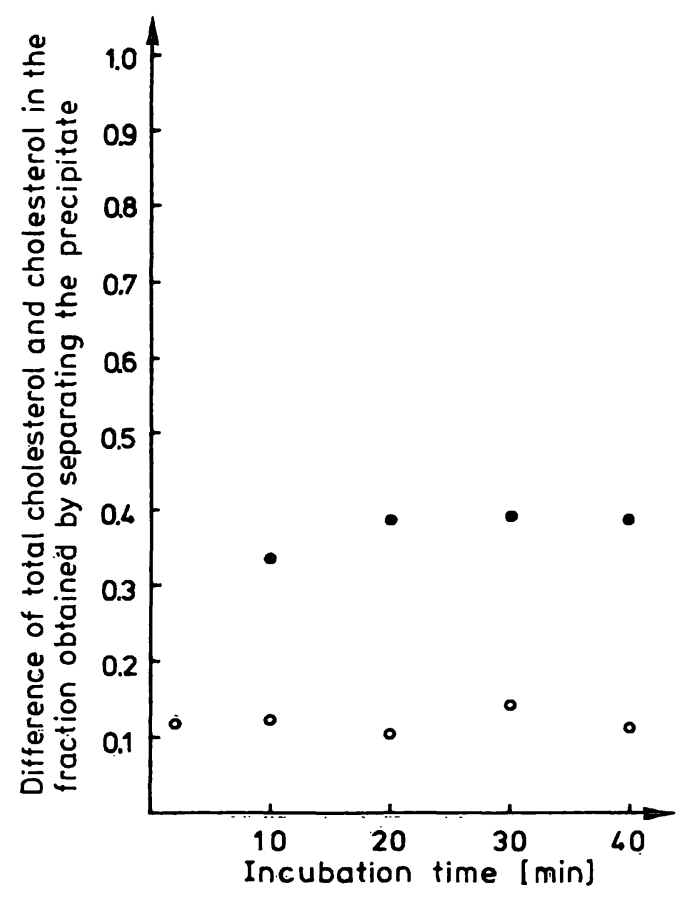

Fig. 4. Difference between cholesterol values measured in serum and those measured in the fraction following precipitation of VLDL with phosphotungstic acid/ $/ \mathrm{MgCl}_{2}$ as a function of incubation time.

$\mathrm{O}=$ incubation at $25^{\circ} \mathrm{C}$

$\boldsymbol{0}=$ incubation at $0^{\circ} \mathrm{C}$

The cholesterol values ascertained in the precipitate were not influenced by centrifugation times between 4 and 10 minutes.

Storage of the samples for 14 days at $+4{ }^{\circ} \mathrm{C}$ did not affect the recovery of cholesterol in the supernatant obtained by separating the precipitate, whereas pre- cipitation of VLDL in samples which had been stored at $-18^{\circ} \mathrm{C}$ resulted in clear coprecipitation of other lipoproteins, irrespective of the length of storage.

\section{Quality control}

Conventional lyophilised control materials proved to be inadequate for testing the precision and accuracy of the LDL cholesterol and LDL apolipoprotein B determination. Precision control was, however, carried out using pool serum which had been stored in portions at $-20^{\circ} \mathrm{C}$. Cholesterol values in VLDL free material which had been frozen were clearly lower than those found in fresh samples. A further change in these values in samples stored at $-20^{\circ} \mathrm{C}$ for more than six months was, however, not observed.

When testing for accuracy, only fresh serum samples were found to be suitable, i.e. samples which had been stored at $+4{ }^{\circ} \mathrm{C}$ for up to 14 days.

\section{Discussion}

The analysed precipitation of VLDL in serum using phosphotungstic acid/ $\mathrm{MgCl}_{2}$ was first mentioned by Burstein et al. (8) and recently used by Sirowej et al. (7) for the selective precipitation of lipoproteins in serum. Investigation of the method described by $\mathrm{Si}$ rowej et al. (7) showed that the specific precipitation of VLDL requires concentrations of phosphotungstic acid and magnesium chloride different from those described by the authors; this is probably due to charge specific variations in phosphotungstic acid.

According to our results VLDL precipitation was only complete and selective within a limited cholesterol and triglyceride area of the serum using a fixed concentration of phosphotungstic acid and $\mathrm{MgCl}_{2}$ in the precipitation assay. To increase linearity of the method we developed three different precipitation procedures depending on the cholesterol and triglyceride content of the serum. Our results demonstrated that VLDL is almost completely precipitated in the tested concentration range of 3 and $10 \mathrm{mmol} / \mathrm{l}$ cholesterol and 1-4 mmol/1 triglycerides in serum, respectively, with negligible coprecipitation of HDL, but with $40-50 \%$ coprecipitation $L p(a)$. Since the comparison of our results obtained by ultracentrifugation $(\mathrm{d}>1.006 \mathrm{~kg} / \mathrm{l})$ and by precipitation showed a good measure of agreement, a coprecipitation of LDL cannot be significant. This was also demonstrated by the excellent agreement of apolipopro- 
tein $B$ determinations in VLDL-free serum (obtained by precipitation) and the $d>1.006 \mathrm{~kg} / \mathrm{l}$ ultracentrifugation fraction. It is noteworthy that the combined procedure of VLDL precipitation and HDL cholesterol determination allows for the quantitative determination of LDL cholesterol (LDL cholesterol $=$ cholesterol in VLDL free fraction $\mathrm{HDL}$ cholesterol). The coprecipitation of $\mathrm{LP}(\mathrm{a})$ is a possible disadvantage for the accurate determination of LDL cholesterol. In sera containing measurable $\mathrm{Lp}(\mathrm{a})(>0.10 \mathrm{~g} / \mathrm{l})$ the $\mathrm{LDL}$ cholesterol values (or LDL apolipoprotein $B$ values) can be calculated by appropriate corrections ( $\mathrm{Lp}(\mathrm{a})$ contains approximately $42 \%$ cholesterol and $18 \%$ apolipoprotein B (14)).

A number of disadvantages seem to make the method described here unsuitable for routine use. For in- stance the accuracy of the values depends to a high degree upon the precise adherence to the reagent concentration used in the precipitation assay (which depends on the cholesterol and triglyceride content of the sera), as well as the incubation temperature. In spite of these disadvantages this method is certainly cheaper and less time consuming than ultracentrifugation which is used as a reference method. Further, in contrast to the Friedewald formula, LDL cholesterol can be measured with relatively high accuracy in VLDL free serum by subtraction of HDL cholesterol. In addition, this method allows a relatively reliable determination of LDL apolipoprotein B using kinetic nephelometry. In view of the data relating to precision and accuracy, the deployment of the described method may be commendable for the research laboratory.

\section{References}

1. Gofman, J. W., Lindgren, F., Elliot, A., Mantz, W., Hewitt, J., Strisower, B., Herring, B., Herring, V. \& Lyon, T. P. (1950) Science 111, 166-171.

2. Castelli, W. P., Doyle, J. T., Gordon, T., Hames, C. G., Hjortland, M. C., Hulley, S. B., Kagan, A. \& Zukel, W. J. (1977) Circulation 55, 767-772.

3. Gordon, T., Castelli, W. P., Hjortland, M. C., Kannel, W. B. \& Dawber, T. R. (1977) Ann. Int. Med. 87, 393-397.

4. Yaari, S., Goldbourt, U., Even-Zohar, S. \& Neufeldt, H. N. (1981) Lancet $I, 1011-1015$.

5. Friedewald, W. T., Levy, R. I. \& Fredrickson, D. S. (1972) Clin. Chem. 18, 499-509.

6. Assmann, G. \& Schriewer, H. (1980) Münch. Med. Wochenschr. 122, 449-452.

7. Sirowej, H., Krieger, R. \& Kattermann, R. (1982) J. Clin. Chem. Clin. Biochem. 20, 875-881.
8. Burstein, M., Scholnick, H. R. \& Morfin, R. (1970) J. Lipid Res. 11, 583-595.

9. Assmann, G., Oberwittler, W., Schulte, H., Schriewer, H., Funke, H., Epping, P. H. \& Hauss, W. H. (1980) Internist 2l, 446-459.

10. Fielding, C. J. (1979) Biochim. Biophys. Acta 573, 255-265.

11. Schriewer, H., Jabs, H.-U., Schultze, J. \& Assmann, G. (1982) Clin. Chim. Acta 123, 139-144.

12. Assmann, G., Schriewer, H. \& Funke, H. (1981) J. Clin. Chem. Clin. Biochem. 19, 273-278.

13. Laurell, C. B. (1972) Scand. J. Clin. Lab. Invest. 29, Suppl. $124,21-37$.

14. Albers, J. J. \& Hazzard, W. R. (1974) Lipids 9, 15-26.

Professor Dr. H. Schriewer

Zentrallaboratorium

der Medizinischen Einrichtungen,

Westfälische Wilhelms-Universität,

Albert-Schweitzer-Straße 33

D-4400 Münster 